\title{
Improvisation and Exhaustion
}

\section{Kevin McNeilly}

In these exhausting times, in this troubled and exhausted world, what might the improvising arts still be good for?

To start to respond to this provocative question, I want to take Lorna Goodison at her word. In "Keith Jarrett-Rainmaker," a meditative lyric from her 1984 collection I Am Becoming My Mother, the Jamaican-born poet situates herself in a conflicted moment of exhaustion, her desiccated spirit "seared" by the "vengeance" of the sun. She describes her own spare, thin lines in the poem as blurry, mixing severe want with a few vestiges of promise, traces of hope for remedy or even survival, recognizing how the sun's warmth might revitalize even as it dries and evoking a Marley-like "song of redemption" that conjures "petals of resurrection / lilies." But what's really needed, she asserts, is rain: "So my prayers are usually / for rain." The poem becomes a form of prayer not, in this instance, supplicant to a withdrawn or uncertain divinity, but instead as an evocation of openness to a particular impossibility, a coincidence of the extemporal and the a-temporal in a moment of close listening. Rain answers her prayer for vitality, but as an improvised coincidence-a brief shower-of musical, or at least aural, attentions.

Here's what I mean. The poem opens by formally hailing Keith Jarrett as her "Piano man," an evocation that positions the pianist as substitute celebrant, an embodiment of what might remain of holy spirit, of temporary divinity. Goodison appears, a bit to her own surprise, to be praying both to and with Jarrett, or maybe Jarrett's music. About halfway down the page of her text, it becomes apparent that she's describing how she has been listening to a Keith Jarrett record while a rainstorm builds outdoors:

l'll be alright if you pull down

for me, waterfalls of rain.

I never thought a piano

could divine,

but l'm hearing you this morning

and right on time

it's drizzling now,

I'll open the curtains and

watch the lightning conduct

your hands. (81)

I'm imagining, though I can't say why (she never specifies, but I have always associated this recording with textures of rainfall), that the soundtrack to Goodison's poem might be the final minutes of Part A / Side 1 of The Köln Concert. But whatever the music, what's significant here is how Goodison points toward coincidence as destiny: rain and music come together "right on time"; they synch up. Both album and poem are mimeses (whether as audio recording or as verbal description) of spontaneous and unrepeatable events, the music embedded and redescribed (at least affectively) in the text. Improvisation, whether as aesthetic technique or as everyday nonchalance (in the opening of curtains, for example), inheres in what the philosopher Vladimir Jankélévitch names irreversibility, the palpable forward motion of time itself. Yet, both forms of documentation-audio tape and verbal transcript-offer to recover lost moments in the present tense, not as memory but as artificial recurrence, one instance of which Goodison's 
poem dramatizes, and even re-enacts. To be "right on time" is much more than the contrived synchrony of a type of pathetic fallacy, when affect seems to overlap causality, the music appearing to make it rain. Embedded in a kind of aural hysteresis, which Goodison calls "hearing you," rain and lightning (as displaced enlightenment or gnosis, perhaps) conduct Jarrett's hands, playing in another time and place, just as his touch on the piano keys pulls down the storm. Prayer becomes haptic, a reciprocity of attunement and returned touch that, instead of closing into some strict form of coinciding, opens a window, akin to the threshold of an attentive ear, onto the revitalized world outwith.

But how long and with what energies can such prayerfulness, such hopeful openness, be sustained? In The Fierce Urgency of Now, Daniel Fischlin, Ajay Heble and George Lipsitz-two of whom are co-editors of this journal-advocate for a "life-affirming imperative" in improvised art, particularly "evident throughout the history of African American improvised musicking," that urges listeners and practitioners "to sound truth to power, [ . . ] to prompt and promote resistance, activism, and mobility in relation to institutions of history-making and knowledgeproduction" (56). With the rise of conservative populisms, authoritarian governments, and suppressive social and cultural regimes globally, such an imperative can feel all the more palpably urgent, and all the more daunting. Present-tense urgency, lately, must also be as extemporaneously exhausting as it is potentially enlivening. The resources of hope might seem a little tapped out, the indefatigable utopian impulses to make a better world a little too on-thenose, a little fatigued.

In September, during a concert break at the Guelph Jazz Festival, I was talking with Ajay Heble about Keith Jarrett's recent four-CD boxed set of solo concerts, A Multitude of Angels (ECM, 2016). He said he was looking forward to picking up a copy, and I mentioned that I had already bought one but hadn't really listened through. (There is a little less than five hours of music there, in total.) I think I also mischaracterized the music when I tried to describe it, so when I returned home to Vancouver, I searched out my copy and, over the course of several days, sat with it and listened. The four concerts, recorded in Italy in October 1996, represent not only the last time Jarrett played long-form piano improvisations, but the last recorded music before he became seriously ill with Chronic Fatigue Syndrome and had to stop playing altogether. The title quotes from the Christmas story in the King James translation of the Gospel of Luke; I'm not sure I hear any related hymns quoted in his performances. In his liner notes, dated May 9, 2016, nearly twenty years later, Jarrett counterpoints exhaustion and inspiration, fate and contingency, in his retrospective account of his own playing, suggesting a spiritual presence close to what Lorna Goodison calls "prayer":

I have heard these concerts many times in the last months and believe they represent a "pinnacle" of my career. Fate has played an enormous part in the result, whether it was being struck by an unknown (at the time) disease, or [. . . ] playing for my life [. . . (I felt it was the last time) [Angels] took their places aside of me and urged me, gently, to go on. After these concerts were over, I couldn't play at all for two years and, without the support of the one angel in my house, I may never have played again.

"I swear," Jarrett writes: "the angels were there." But as Rilke among others reminds us, angels can both sustain and terrify. There is a moment about thirty minutes into the penultimate concert at Torino, when Jarrett's inspiration audibly and palpably appears to fail him. He seems to be in mid-flight, pursuing a rising fragment of melody when his touch doesn't so much falter as recede, growing frailer. It's not that he loses the thread of his line, but that he lets go of his trajectory. The first time I heard this recording, the seconds of quiet, the tacit break that followed this fracture, this musical wound, felt (to coin a cliché) like an eternity. Listening back, it's clear 
he will tentatively, and then with increasing firmness, find his way forward into improvising again, but the sense remains around those seconds not of deliberate pause so much as a failure of agency, of fatigue. Jarrett both improvises his own fatigue, and then improvises through it and apart from it. He plays-and also unplays, redacting the irreversible-for his life.

Simone Weil has characterized the beauty in empathetic listening, particularly listening for and to affliction, or hurt or pain, as taking "the form of a wound. Vitality and hurt are bound up in the intersections of improvisation and exhaustion, as Fred Moten asserts in the preface to Black and Blur, the first volume of his recent critical trilogy, consent not to be a single being:

This is why, as Wadada Leo Smith has said, it hurts to play this music. The music is a riotous solemnity, a terrible beauty. It hurts so much that we have to celebrate. That we have to celebrate is what hurts so much. Exhaustive celebration of and in and through our suffering, which is neither distant nor [remedially] sutured, is black study. (xiii)

An improvisatory aesthetic of exhaustion and the exhaustive emerges from Afrological musicking ("my roots are african," Goodison's poem proclaims), but such work is also sutured, if only provisionally, to some form of healing. "Some of my worst wounds," Goodison writes elsewhere, "have healed into poems" (108).

But it's also clear, in these exhausting times, that the musical, theatrical, textual, and even social improvisatory arts likely offer more possibility than panacea, that such work is as effortful as it is enabling. In a public interview with Professor David Gaertner at the University of British Columbia on March 16, 2018, ahead of a three-concert run at the Chan Centre, Inuk avantgarde throat-singer Tanya Tagaq and Greenlandic mask dancer Laakkuluk Williamson Bathory spoke forcefully about what Laakkuluk called "reconciliation fatigue [. . .] the unresolved state of things." How long, they both asked, do we need to wait for things to change and for a just world? How much, Tanya Tagaq asked, "do we have to tolerate peacefully?" Here, they said, gesturing at their audience, "you take it," as if to make some headway distributing the burdens of representation and advocacy. "It's unfair that we have to carry it all," said Laakkuluk. "All we can do," said Tagaq, "is reach out in hope." The crucial form of that outreach, Tagaq asserted, in response to a question about how exhausting it must be to perform extemporaneously with her trio for eighty-odd minutes straight, is improvisation. "If you're true to yourself," she responded, "improvisation is not exhausting but rejuvenating." l'd suggest that, when it succeeds, improvising creates associative networks of reciprocities, a give and take that, "right on time," doesn't so much bridge divergences and differences as activate a risky opening up, an empathy. It gets you a little ways "out of your own body," as Tanya Tagaq put it: "Improvisation helps."

Each of the essays in this issue maps, in its own way and on its own terms, an address to this fatigued world with an offer of sincere and open-handed help.

\section{Works Cited}

Fischlin, Daniel, et al. The Fierce Urgency of Now: Improvisation, Rights, and the Ethics of Cocreation. Duke UP, 2013.

Goodison, Lorna. Collected Poems. Carcanet, 2016.

Jarrett, Keith. A Multitude of Angels: Modena Ferrara Torino Genova Solo Concerts, compact discs, ECM 2500-03, 2016. 
Moten, Fred. Black and Blur. Duke UP, 2017.

Tagaq, Tanya, and Laakkuluk Williamson Bathory. Interviewed by Professor David Gaertner. University of British Columbia, Vancouver, Canada, 16 Mar. 2018.

Weil, Simone. "What is Sacred in Every Human Being?" Late Philosophical Writings. Translated by Eric O. Springsted and Lawrence E. Schmidt, U of Notre Dame P, 2015. 